\title{
Short Communication: Identification of Leptin gene in crossbred beef cattle
}

\author{
LAKSA ERSA ANUGRATAMA", TETY HARTATIK ${ }^{\text {"v }}$ \\ Department of Animal Breeding and Reproduction, Faculty of Animal Science, Universitas Gadjah Mada. Jl. Fauna No. 03, Bulaksumur, Sleman 55281, \\ Yogyakarta, Indonesia. Tel.: +62-274-513363, •email: laksa.e@mail.ugm.ac.id, •vemail: tety@ugm.ac.id
}

Manuscript received: 10 November 2019. Revision accepted: 23 December 2019.

\begin{abstract}
Anugratama LE, Hartatik T. 2020. Short Communication: Identification of Leptin gene in crossbred beef cattle. Biodiversitas 21: 226-230. Leptin is a gene that affects animal weight. Leptin gene is known to control body weight, feed intake, energy expenditure, immune function, and reproduction. This study aims to identify the diversity of the Leptin gene in crossbred beef cattle, Sumba Ongole cattle, Brahman cross cattle, Bali cattle, buffalo, sheep, and goat by comparing with four GenBank data of cattle. Crossbred beef cattle obtained from Klaten, Central Java, Indonesia. Leptin nucleotide sequences were analyzed using BioEdit to identify Single Nucleotide Polymorphism (SNP). To create amino acid change in Leptin gene, the coding sequence of exon 2 was established using BioEdit ver. 7.0.5. Phylogenetic tree and genetic distance have been analyzed based on the Leptin gene using MEGA 10.1.1 program. The result shows that eight variations of SNP were found in exon 2. The phylogenetic tree represents that crossbreed beef cattle, Sumba Ongole cattle, Brahman cross cattle, Bali cattle, Bos taurus, Bos indicus, Bos frontalis, Bos grunniens, Bubalus bubalis are in the same cluster with various genetic distance. The results of this study are expected to provide genetic information that will be used for further research on the relationship between Leptin gene polymorphisms to animal weight.
\end{abstract}

Keywords: GenBank, Leptin gene, phylogenetic, single nucleotide polymorphism

Abbreviations: DNA: Deoxyribo Nucleic Acid, MAS: Marker-Assisted Selection, mRNA: messenger Ribonucleic Acid, NCBI: National Center for Biotechnology Information, SNP: Single Nucleotide Polymorphism

\section{INTRODUCTION}

One of the genes that affect animal weight is the Leptin / LEP gene (Hernandez et al., 2016). Leptin is a hormone that is produced in white adipose tissue and secreted into the bloodstream as a $16 \mathrm{KD}$ protein. It plays important roles in the control of body weight, feed intake, energy expenditure, immune function and reproduction (Fruhbeck et al., 1998). The versatile hormone Leptin is one of the key factors regulating meat quality traits. Numerous studies show close relationships between Leptin gene polymorphisms and carcass and meat quality traits of beef cattle (Buchanan et al., 2002). Leptin single nucleotide polymorphisms (SNPs) in cattle have been significantly associated with serum leptin concentration as well as with backfat thickness, marbling score and live and hot weight at slaughter (Nkrumah et al., 2005). Chung et al. (2008) have also shown a close relationship between Leptin gene polymorphisms and carcass and meat quality traits of Korean beef cattle. Markers in the Leptin gene are already part of commercial genotyping panels designated for Marker-Assisted Selection (MAS) in beef cattle. Barzehkar et al. (2009) have reported associations of A113G polymorphism in the Leptin gene with marbling in Iranian sheep. Buchanan et al. (2002) reported changes in the mutation of the $\mathrm{C} 1180 \mathrm{~T}$ nucleotide sequence that caused changes in the coding of proteins from Arginine to
Cysteine (Arg25Cys), these changes affect the physiological function of Leptin in the metabolic process.

To identify the diversity of Leptin gene can use bioinformatics. Bioinformatics can be defined as the application of computer technology to the management of biological information. Bioinformatics is the science of storing, extracting, organizing, analyzing, interpreting and utilizing information from biological sequences and molecules. Bioinformatics tools that can be used for analysis Leptin gene such as sequence alignment, multiple sequence alignment, gene finding, protein domain analysis, pattern identification, genomic analysis, motif finding (Raza 2012). The program that usually uses deoxyribonucleic acid (DNA) alignment and compares two or more sequences is the BioEdit program (offline) and Mega 10. Mega 10 also can be used to construct phylogenic tree and genetic distance.

This study aims to identify the diversity of the Leptin gene in crossbred beef cattle (Bos Taurus x Bos indicus), Bali cattle (Bos sondaicus syn. Bos javanicus javanicus), Sumba Ongole (Bos indicus), Brahman cross (Bos indicus), buffalo, sheep, and goat by comparing the DNA sequence of Leptin gene from DNA samples of this study and GenBank data. The results of this study are expected to provide genetic information that will be used for further research on the relationship between Leptin gene polymorphisms to animal growth, feed conversion efficiency, and health. 


\section{MATERIALS AND METHODS}

\section{Study area}

This research was done at the Laboratory of Genetic and Animal Breeding, Faculty of Animal Science, Universitas Gadjah Mada, Yogyakarta, Indonesia. The study was conducted from April to August 2019. Analysis of sequencing was performed at LPPT, Universitas Gadjah Mada. The materials used in this study were blood samples of crossbred beef cattle, Sumba Ongole cattle, Brahman cross cattle, Bali cattle and nine sequences of Leptin gene from Bos taurus (U50365.1), Bos indicus (EU313203.1), Bos grunniens (EU603265.1), Bos frontalis (EU642566.1), Bubalus bubalis (AH013754.2), Capra hircus (JQ739232.1, JQ739233.1, GU944974.2), Ovis aries (HE605296.1) which is obtained from NCBI GenBank data.

\section{Procedures}

\section{Sample collection}

Five blood samples were collected from crossbred beef cattle, one sample from Sumba Ongole cattle, and three samples from Bali cattle. The blood samples were taken from the jugular vein using venoject connected to a vacutainer containing an anticoagulant $\mathrm{K}_{3}$ EDTA. $\mathrm{K}_{3}$ EDTA serves to prevent blood clots from forming in the vacutainer. The samples were stored in a freezer at $-20^{\circ} \mathrm{C}$.

\section{DNA extraction}

Isolation of DNA was performed using Extraction Kit (Geneaid, Taiwan) in the Laboratory of Genetic and Animal Breeding, Faculty of Animal Science, Universitas Gadjah Mada, Yogyakarta, Indonesia.

\section{DNA amplification and sequencing}

Five genomic DNA samples from Crossbred beef cattle, one sample from Sumba Ongole cattle, and three samples from Bali cattle were amplified used PCR method to get targeted sequence. The primer that used for PCR amplification of targeted sequence of Leptin gene is forward F: 5'-AGCGGTTATGGGATATGCC-3' and reverse is R: 5'-AATGCCCCAAGAGACACTGA-3' with 961 bp DNA fragments gene located in the part of intron 1, exon 2, and part of intron 2. Polymerase Chain Reaction performed in a total reaction of $25,5 \mu \mathrm{l}$, containing $12,5 \mu \mathrm{L}$ PCR Kit (KAPA BIOSYSTEMS, USA), $10 \mu \mathrm{L}$ aquabidest, $1.5 \mu \mathrm{L}$ of DNA, $1.5 \mu \mathrm{L}$ of both forward and reverse primers. The reactions were performed using a thermal cycle (PEQLAB Primus 25 advanced, Germany) with a pre-denaturation temperature at $94^{\circ} \mathrm{C}$ for 1 minute, followed by 30 cycles of reaction; denaturation at $94^{\circ} \mathrm{C}$ for 1 minute, annealing at a temperature of $57^{\circ} \mathrm{C}$ for 1 minute and extension at $72^{\circ} \mathrm{C}$ for 1 minute, then the last step was a final extension at $72^{\circ} \mathrm{C}$ for 5 minutes. The quality of the PCR product was determined using gel electrophoresis $(1 \%)$, the thick and DNA bands were the preferred result (Fathoni et al., 2018). The targeted sequence was sequencing analyzed by LPPT UGM.

\section{Comparison analysis}

Single nucleotide polymorphism identification, comparison sequences, and amino acid change were performed using BioEdit software. A total of 18 sequences of Leptin gene (four Crossbred beef cattle, one sample Sumba Ongole cattle, one sample Brahman cross cattle, three sample form Bali cattle and nine GenBank sequences were aligned using ClustalW on BioEdit ver. 7.0.5 to reveal the SNPs and to perform the amino acid change. Phylogenetic tree and genetic distance have been analyzed based on the Leptin gene. The genetic distance and phylogenetic tree were displayed based on Kimura method (Kimura, 1980) using Mega 10.1.1 program.

\section{RESULTS AND DISCUSSION}

The target DNA in this study was Leptin gene fragment in the intron 1, exon 2, and intron 2 regions based on GenBank acc no. U50365.1, but only exon 2 was analyzed for identification of amino acid change in crossbred beef cattle (Figure 1, Table 2). Exon 2 was located at sequence no 1108 to 1251 of GenBank acc no. U50365.1. This study was the first to identify SNPs in the Leptin gene on several sequences from DNA sample of crossbred beef cattle, Sumba Ongole cattle (Bos indicus), Brahman cross cattle (Bos indicus), Bali cattle (Bos sondaicus), and GenBank of Bos taurus (U50365.1), Bos indicus (EU313203.1), Bos grunniens (EU603265.1), Bos frontalis (EU642566.1), Bubalus bubalis (AH013754.2), Capra hircus (JQ739232.1，JQ739233.1， GU944974.2), Ovis aries (HE605296.1) sequences were aligned using BioEdit program. As the result, eight SNPs were identified in exon 2 region: g.1120 C>T, g.1128 T>C, g.1130 G>A, g.1155 $\mathrm{G}>\mathrm{C}$, g. $1158 \mathrm{~T}>\mathrm{C}$, g. $1180 \mathrm{C}>\mathrm{H}$, g. $1181 \mathrm{G}>\mathrm{A}$, g. $1218 \mathrm{~A}>\mathrm{G}$. The SNPs presented in Table 1. Four individual genotype of crossbred beef cattle, Sumba Ongole, and Bali cattle base on sequence analysis has been submitted to the GenBank with the accession number MN709606 (Sumba Ongole, SO_01), MN709607 (Brahman cross, BX392), MN 709608 ( Belgian Blue F2020), and MN709609 (Bali cattle, B2013-160).

Based on the result of sequence alignment, 8 SNPs have been found in the CDS region. One SNP was heterozygous for Sumba Ongole and crossbred beef cattle at SNP g.1180 C>Y. Single nucleotide polymorphism g.1180 C>Y was identified by the presence of "double peak". The SNP was resulting in two alleles, $\mathrm{C}$ and $\mathrm{T}$ (Figure 2). Single nucleotide polymorphism can cause changes in amino acids. These changes can be either silent or missense. A silent mutation occurs if the SNP only changes the DNA but does not change the amino acid. Missense mutation will occur if the SNP not only change the DNA but also an amino acid. The results of this study found 4 SNPs were silent and 4 SNPs missense which can be seen in Table 2. 


\begin{abstract}
AGCGGTTATGGGATATGCCTGCAGTCGTACAGCTATTAAATGTCTGGATTCAAACCAGACCTTGAAAGCCC GCCGTCCACCCGCTCGTGCCCTGGCTCACTGCTGCGTGGTCTACAGCACACCTCCTGTGGTTTTCTTGATT CCGCCGCACCTCTCCCCAGGGGAGTGCCTTTCATTACTGTCATTTCTAGACAATGAATTGTCTTTGAGGAG ATGATAGCCATGGCAGACAGCAAATCTCGTTGTTATCCGCATCTGAAGACCTGGATGCGGGTGGTAACGGA GCACGTGGGTGTTCTCGGAGATCGACGATGTGCCACGTGTGGTTTCTTCTGTTTTCAGGCCCCAGAAGCCC ATCCCGGGAAGGAAAATGCGCTGTGGACCCCTGTATCGATTCCTGTGGCTTTGGCCCTATCTGTCTTACGT GGAGGCTGTGCCCATCYGCAAGGTCCAGGATGACACCAAAACCCTCATCAAGACAATTGTCACCAGGATCA ATGACATCTCACACACGGTAGGGAGGGACTGGGAGACGAGGTAGAACCGTGGCCATCCCGTGGGGGACCCC AGAGGCTGGCGGAGGAGGCTGTGCAGCCTTGCACAGGCCCCAGTGGCCTGGACGCCCCCCTGGCATAAAGA CAGCTCCTCTCCTCCTCCACTTCCCTTGCCTCCCGCCTTCTCACTCTCCTCCCTCCCAGACCGGAATCCTA GTGCCCAGGCCCAGAAGGAGTCACAGAGGTCCTGGGGTCCCCTTGGCAGGTGGCCAGAACCCCAGCAGCAG TCCCTCTGGGCCTCCATCTCATTTCTAGAATGTTTTAGTCGTTAGGCATTCTTCCTGCCTGGTAACTGAGC TTAGACCCTGCGAGCTCATTACTCATTACTGCCAGCCCTGCCTGTCAAGCCCTCTTCAGATACAACCCTCT GTGTTTTTGTAAATAGTTATCAGTGTCTCTTGGGGCATT
\end{abstract}

Figure 1. Sequence target of Leptin gene in crossbred beef cattle. (Gray shadow=exon 2, H=C/T/A)

Table 1. Alignment of Leptin gene in Bos taurus, Bos indicus, Bos grunniens, Bos frontalis, Bubalus bubalis, Capra hircus, Ovis aries, Brahman cross cattle, Sumba Ongole cattle, Bali cattle, crossbred beef cattle

\begin{tabular}{|c|c|c|c|c|c|c|c|c|c|c|c|}
\hline $\begin{array}{c}\text { SNP } \\
(\mathbf{U 5 0 3 6 5 . 1 )}\end{array}$ & $\begin{array}{c}\text { Bos } \\
\text { taurus }\end{array}$ & $\begin{array}{c}\text { Bos } \\
\text { indicus }\end{array}$ & $\begin{array}{c}\text { Bos } \\
\text { grunniens }\end{array}$ & $\begin{array}{c}\text { Bos } \\
\text { frontalis }\end{array}$ & $\begin{array}{l}\text { Bubalus } \\
\text { bubalis }\end{array}$ & $\begin{array}{l}\text { Capra } \\
\text { hircus }\end{array}$ & $\begin{array}{l}\text { Ovis } \\
\text { aries }\end{array}$ & $\begin{array}{c}\text { Brahman cross } \\
\text { cattle (Bos } \\
\text { indicus) }\end{array}$ & $\begin{array}{c}\text { Sumba } \\
\text { Ongole (Bos } \\
\text { indicus) }\end{array}$ & $\begin{array}{c}\text { Bali cattle (Bos } \\
\quad \text { sondaicus) }\end{array}$ & $\begin{array}{l}\text { Crossbred } \\
\text { beef cattle }\end{array}$ \\
\hline $1120 \mathrm{C}>\mathrm{T}$ & $\mathrm{C}$ & $\mathrm{C}$ & $\mathrm{T}$ & $\mathrm{C}$ & $\mathrm{C}$ & $\mathrm{C}$ & $\mathrm{C}$ & $\mathrm{C}$ & $\mathrm{C}$ & $\mathrm{C}$ & $\mathrm{C}$ \\
\hline $1128 \mathrm{~T}>\mathrm{C}$ & $\mathrm{T}$ & $\mathrm{T}$ & $\mathrm{T}$ & $\mathrm{T}$ & $\mathrm{C}$ & $\mathrm{C}$ & $\mathrm{C}$ & $\mathrm{T}$ & $\mathrm{T}$ & $\mathrm{T}$ & $\mathrm{T}$ \\
\hline $1130 \mathrm{G}>\mathrm{A}$ & $\mathrm{G}$ & $\mathrm{G}$ & $\mathrm{G}$ & $\mathrm{G}$ & A & $\mathrm{G}$ & $\mathrm{G}$ & $\mathrm{G}$ & $\mathrm{G}$ & $\mathrm{G}$ & $\mathrm{G}$ \\
\hline $1155 \mathrm{G}>\mathrm{C}$ & G & G & G & G & $\mathrm{G}$ & $\mathrm{C}$ & $\mathrm{C}$ & G & G & G & G \\
\hline $1158 \mathrm{~T}>\mathrm{C}$ & $\mathrm{T}$ & $\mathrm{T}$ & $\mathrm{C}$ & $\mathrm{C}$ & $\mathrm{C}$ & $\mathrm{C}$ & $\mathrm{C}$ & $\mathrm{T}$ & $\mathrm{T}$ & $\mathrm{T}$ & $\mathrm{T}$ \\
\hline $1180 \mathrm{C}>\mathrm{H}$ & $\mathrm{C}$ & $\mathrm{C}$ & A & A & $\mathrm{C}$ & $\mathrm{C}$ & $\mathrm{C}$ & $\mathrm{C}$ & $\mathrm{Y}$ & $\mathrm{C}$ & $\mathrm{Y}$ \\
\hline $1181 \mathrm{G}>\mathrm{A}$ & G & $\mathrm{G}$ & $\mathrm{G}$ & G & $\mathrm{G}$ & G & G & G & G & A & G \\
\hline $1218 \mathrm{~A}>\mathrm{G}$ & $\mathrm{G}$ & $\mathrm{G}$ & $\mathrm{G}$ & $\mathrm{G}$ & $\mathrm{G}$ & $\mathrm{G}$ & $\mathrm{G}$ & $\mathrm{G}$ & $\mathrm{G}$ & A & $\mathrm{G}$ \\
\hline
\end{tabular}

Note: $\mathrm{A}$ is Adenin, $\mathrm{C}$ is Cytosine, $\mathrm{G}$ is Guanine, $\mathrm{T}$ is Thymin, $\mathrm{Y}$ is pYrimidine that base $(\mathrm{C} / \mathrm{T}), \mathrm{H}$ that base $(\mathrm{C} / \mathrm{T} / \mathrm{A})$

Table 2. Amino acid analysis in CDS exon 2 of Leptin gene

\begin{tabular}{|c|c|c|c|}
\hline $\begin{array}{c}\text { SNP } \\
(\mathbf{U 5 0 3 6 5 . 1})\end{array}$ & Codon & Amino Acid & Mutation \\
\hline \multirow[t]{2}{*}{$1120 \mathrm{C}>\mathrm{T}$} & $\mathrm{CCC}$ & Proline (Pro) & Missense \\
\hline & TCC & Serine (Ser) & \\
\hline \multirow[t]{2}{*}{$1128 \mathrm{~T}>\mathrm{C}$} & TAT & Tyrosine (Tyr) & Silent \\
\hline & TAC & Tyrosine (Tyr) & \\
\hline \multirow[t]{2}{*}{$1130 \mathrm{G}>\mathrm{A}$} & GGA & Arginine (Arg) & Missense \\
\hline & CAA & Glutamine (Gln) & \\
\hline \multirow[t]{2}{*}{$1155 \mathrm{G}>\mathrm{C}$} & CTG & Leucine (Lys) & Silent \\
\hline & CTC & Leucine (Lys) & \\
\hline \multirow[t]{2}{*}{$1158 \mathrm{~T}>\mathrm{C}$} & TCT & Serine (Ser) & Silent \\
\hline & TCC & Serine (Ser) & \\
\hline \multirow[t]{4}{*}{$1180 \mathrm{C}>\mathrm{H}$} & CGC & Arginine (Arg) & Missense \\
\hline & YGC & Arginine/Cysteine & \\
\hline & $\mathrm{AGC}$ & Serin (Ser) & \\
\hline & TGC & Cysteine (Cys) & \\
\hline \multirow[t]{2}{*}{$1181 \mathrm{G}>\mathrm{A}$} & CGC & Arginine (Arg) & Missense \\
\hline & CAC & Histidine (His) & \\
\hline \multirow[t]{2}{*}{$1218 \mathrm{~A}>\mathrm{G}$} & $\mathrm{ACA}$ & Threonine (Thr) & Silent \\
\hline & $\mathrm{ACG}$ & Threonine (Thr) & \\
\hline
\end{tabular}

Note: Coding Sequences (CDS) are sequences of DNA that encode proteins from the start codon to the stop codon. This study only identifies CDS because mutations that occur in CDS can cause changes in amino acids. Changes in amino acids affect the phenotype.
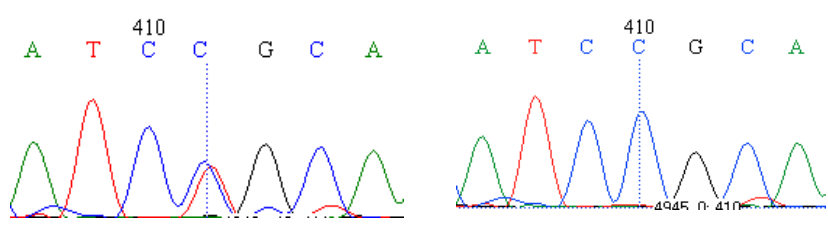

Figure 2. The Electropherogram indicated the polymorphism of Leptin gene in crossbred beef cattle (SNP g. 1180 C>Y). Heterozygote CT (left) and homozygote CC (right). Homozygote TT was not available in crossbred beef cattle.

Missense mutation SNPs founded on g. $1120 \mathrm{C}>\mathrm{T}$, g. $1130 \mathrm{G}>$ A, g. $1180 \mathrm{C}>\mathrm{H}$, g. $1181 \mathrm{G}>$ A. The first SNP g. $1120 \mathrm{C}>\mathrm{T}$ changes amino acid from Proline to Serine. The second SNP g. $1130 \mathrm{G}>\mathrm{A}$ has changed the amino acid Arginine to Glutamine. The third SNP g. $1180 \mathrm{C}>\mathrm{H}$ changes the amino acid Arginine to Cysteine or Serin. The fourth SNP g.1181 G>A also a missense mutation that changes the amino acid from Arginine to Histidine

A phylogenetic tree is a diagram that represents evolutionary relationships among organisms. The phylogenetic tree was constructed based on the Kimura 2parameter model with 1,000 bootstrap replications (Figure 3). As a result of Figure 3, it showed that there were 2 big groups. The Crossbred beef cattle, Sumba Ongole cattle, Brahman cross cattle, Bali cattle, Bos frontalis, Bos grunniens and Buffalo were clustered in one big group, whereas the sheep and goat in other clusters. The cattle groups were separated from sheep and goats. 


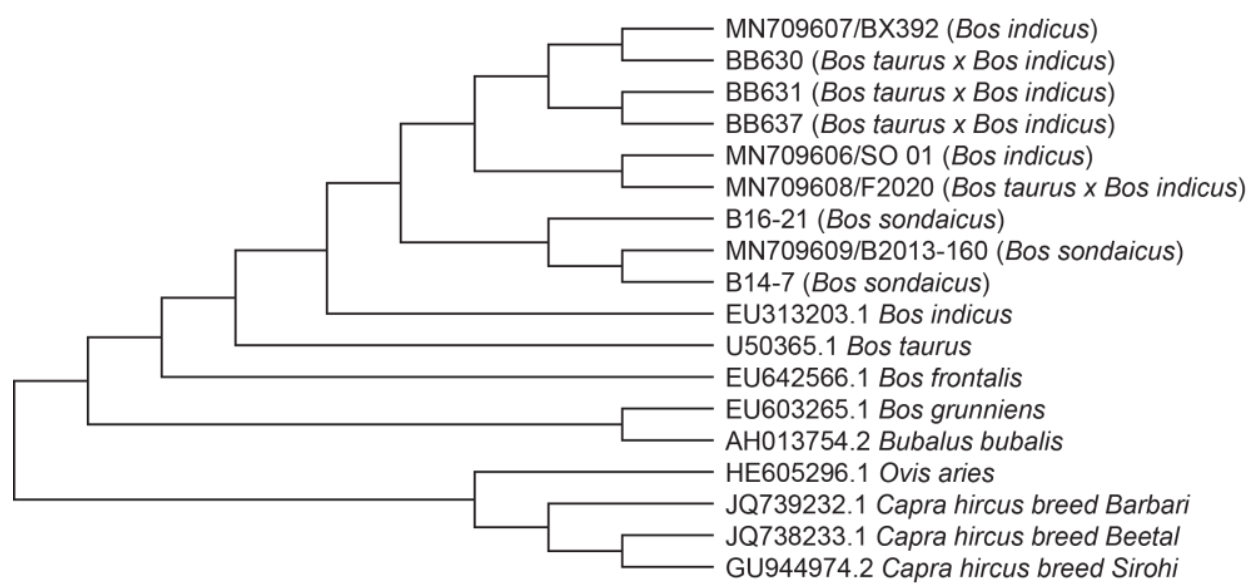

Figure 3. Phylogenetic tree based on Leptin gene

\section{Discussion}

Total of 8 SNPs was presented in Table 1. There were only 4 SNPs that affect the encoded amino acid. SNPs g. $1120 \mathrm{C}>\mathrm{T}$ (Pro/Ser), g. $1130 \mathrm{G}>\mathrm{A}$ (Arg/Gln), g. $1180 \mathrm{C}>\mathrm{H}$ (Arg/Cys/Ser), and g. 1181G $>$ A (Arg/His) was confirmed by BioEdit. SNP g. $1180 \mathrm{C}>\mathrm{Y}$ in crossbred beef cattle was confirmed by electropherogram (Figure 2). It has two alleles C and T. Hernández et al. (2016); Orrù et al. (2011); and Fathoni et al. (2018) also reported that in Brahman; Simmental bulls; and Kebumen Ongole Grade cattle has SNP g. 1180 C > T (Arg/Cys). Fathoni et al. (2018) reported a change in mutation g. $1180 \mathrm{C}>\mathrm{T}$ has significantly associated with high weaning chest circumference in Kebumen Ongole Grade cattle. Javanmard et al. (2010); Buchanan et al. (2002); Konfortov et al. (1999) also reported SNP g. $1180 \mathrm{C}>\mathrm{T}$ change amino acid from arginine to cysteine. Buchanan et al. (2002) reported SNP g.1180 C>T has significant associations between the SNP genotype and carcass fat levels in cattle. Schenkel et al. (2005) reported that this SNP was significantly associated with carcass quality and composition in cattle. Furthermore, Leptin gene had been reported to have an effect on body weight and body size in Chinese cattle (Yang et al., 2007), growth traits in Nellore cattle (Silva et al., 2013).

The phylogenetic relationship of the Leptin gene (Figure 3) explained that the crossbred beef cattle, which belonged to BB630, BB631, BB637, F2020 (MN709608) has a close relationship, Brahman cross cattle (BX392) with GenBank no MN709607, Sumba Ongole cattle (SO 01) with GenBank no MN709606 and Bali cattle (B14-7, B2013-160 [genbank no MN709609], B16-21). The constructed tree demonstrated that our studied sample (Crossbred beef cattle, Brahman cross cattle, Sumba Ongole cattle, and Bali cattle) have a close relationship with Bos indicus than Bos taurus. Also, it showed that the studied sample has a very far relationship with Bos frontalis, Bos grunniens, and Buffalo. The sheep and goats were out of the group of cattle.

Finally, this study has provided information regarding the identification of the Leptin gene in Crossbred beef cattle. Also, we performed a phylogenetic analysis of all samples with other cattle and goat/sheep breeds. 8 SNPs have found in our study, but only 5 SNPs were missense mutations. SNPs g. $1120 \mathrm{C}>\mathrm{T}$ (Pro/Ser), g. $1130 \mathrm{G}>\mathrm{A}$ (Arg/Gln), g. $1180 \mathrm{C}>\mathrm{H}$ (Arg/Cys/Ser), and g. $1181 \mathrm{G}>\mathrm{A}$ (Arg/His) may have potential as a Marker-Assisted Selection (MAS) because missense mutations may have affect to traits of cattle. Crossbred beef cattle were distantly related to Bos taurus, Bos frontalis, and Buffalo. The Crossbred beef cattle may have a unique gene pool compared to these mentioned breeds, so it very interesting for future research.

\section{ACKNOWLEDGEMENTS}

This study was supported by Research Grant Rekognisi Tugas Akhir (RTA) 2019 contract no. 3274/UN/DITLIT/ DIT-LIT/LT/2019 from Ministry of Research, Technology and Higher Education of the Republic of Indonesia, and the sample was supported by PT. Widodo Makmur Perkasa, Klaten, Indonesia. We also would like to thanks to Latifah and Muhsin for the discussion in writing the paper and Riyan Nugroho Aji and Laurentius Lintang for help collecting the samples, and also to Retno Setyawati for helping in laboratory analysis.

\section{REFERENCES}

Barzehkar R, Salehi A, Mahjoubi F. 2009. Polymorphism of the ovine Leptin gene and its association with growth and carcass traits in three Iranian sheep breeds. Iran J Biotechnol 7: 241-246.

Buchanan FC, Fitzsimmons CJ, Van-Kessel AG, Thue TD, WinkelmanSim DC, Schmutz SM. 2002. Association of a missense mutation in the bovine Leptin gene with carcass fat content and Leptin mRNA levels. Genet Sel Evol 34: 105-116.

Chung ER, Shin SC, Shin KH, Chung KY. 2008. SNP discovery in leptin promoter gene and association with meat quality and carcass traits in Korean cattle. Asian Aust J Anim Sci 21: 1689-1695.

Fathoni A, Maharani D, Aji RN, Choiri R, Sumadi S. 2018. Polymorphism of the SNP g. $1180 \mathrm{C}>\mathrm{T}$ in leptin gene and its association with growth traits and linear body measurement in 
Kebumen Ongole grade cattle. J Indon Trop Anim Agricult 44: 125 134.

Fruhbeck G, Jebb SA, Prentice AM. 1998. Leptin: Physiology and pathophysiology. J Clin Physiol 18: 399-419.

Hernandez N, Gonzalez JCM, Bracamonte GMP, Rincon AMS, Villalobos NL, Morris ST, Encinia FB, Rivas EO, Contreras VIP, Garcia LAM. 2016. Association of polymorphisms in growth hormone and leptin candidate genes with live weight traits of Brahman cattle. Genet Mol Res 15: 1-9.

Javanmard, A, N Asadzadeh, F Sarhadi. 2010. DNA polymorphism of bovine pituitary-specific transcription factor and leptin gene between Iranian Bosindicus and Bos taurus cattle. Am J Agric Biol Sci 5 (3): 282-285.

Kimura, M. 1980. A simple method for estimating evolutionary rates of base substitutions through comparative studies of nucleotide sequences. J Mol Evol 16: 111-120

Konfortov BA, Licence VE, Miller JR. 1999. Re-sequencing DNA from a diverse panel of cattle reveals a high level of polymorphism in both intron and exon. Mamm Genome 10: 1142-1145.

Nkrumah JD, Li C, Yu J, Hansen C, Keisler DH, Moore SS. 2005. Polymorphisms in the bovine leptin promoter associated with serum leptin concentration, growth, feed intake, feeding behavior, and measures of carcass merit. J Anim Sci 83: 20-28.

Orrù L, Cifuni GF, Piasentier E, Corazzin M. 2011. Association analyses of single nucleotide polymorphisms in the LEP and SCD1 genes on the fatty acid profile of muscle fat in Simmental bulls. Meat Sci 87 (4): $344-348$

Raza, K. 2012. Application of data mining in bioinformatics. Indian $\mathbf{J}$ Comp Sci Eng 1: 114-118.

Schenkel, FS, Miller SP, Ye X, More SS, Nkrumah JD, Li C, Yu J, Mandell IB, Wilton JW, Williams JL. 2005. Association of single nucleotide polymorphisms in the leptin gene with carcass and meat quality traits of beef cattle. J Anim Sci 83 (9): 2009-2020.

Silva DBS, Crispim BA, Silva LE, Oliveira JA, Siqueira F, Seno LO, Grisolia AB. 2014. Genetic variations in the leptin gene associated with growth and carcass traits in Nellore cattle. Genet Mol Res 13 (2): 3002-3012.

Yang D, Chen H, Wang X, Tian Z, Tang L, Zhang Z, Lei C, Zhang L, Wang Y. 2007. Association of polymorphisms of leptin gene with body weight and body sizes indexes in Chinese indigenous cattle. J Genet Genom 34 (5): 400-405. 